\title{
ANTICANCER POTENTIAL OF N(4)SUBSTITUTED 5- NITROISATIN THIOSEMICARBAZONES AND THEIR COPPER(II) COMPLEXES
}

\author{
N. K. Singh ${ }^{1}$, S. Shrestha ${ }^{2}$, N. Shahi' ${ }^{2}$ R. K. Choudhary ${ }^{3}$, A. A Kumbhar ${ }^{4}$, Y. \\ R. Pokharel ${ }^{2}$ and P. N. Yadav ${ }^{5, \bowtie}$ \\ ${ }^{1}$ Department of Chemistry, Amrit Campus, Tribhuvan University, Kathmandu, Nepal \\ ${ }^{2}$ Faculty of Life Science and Biotechnology, South Asian University, Akbar Bhawan, \\ Chanakyapuri, New Delhi-110021, India \\ ${ }^{3}$ Department of Chemistry, Gurukula Kangri Vishwavidyalaya, Haridwar-249404, India \\ ${ }^{4}$ Department of Chemistry, Savitribai Phule Pune University, Pune, India \\ ${ }^{5}$ Central Department of Chemistry, Tribhuvan University, Kirtipur, Kathmandu, Nepal \\ ${ }^{\square}$ Corresponding Authors: pnyadav219@gmail.com
}

\begin{abstract}
N(4) modified copper thiosemicarbazones have been extensively studied for their anticancer potency toward various cancer cells as they exhibit less toxicity, wide spectrum of activity, non-resistance behavior and a novel mechanism of action as compared to that of platinum complexes. 5-Nitroisatin -4-thiomorpholinyl-3-thiosemicarbazone $\left(\mathrm{L}_{1}\right)$, 5nitroisatin -4, 4-dimethyl-3-thiosemicarbazone $\left(\mathrm{L}_{2}\right)$, and their copper (II) complexes; $\mathrm{CuL}_{1}$ and $\mathrm{CuL}_{2}$ were prepared and characterized by elemental analysis, FTIR, NMR, ESI-HRMS, UV-Vis, TGA, PXRD (Le Bail fitting) and EPR techniques. PXRD analysis suggested that the copper (II) complexes possess a monoclinic crystal system with P12 1 symmetry. The coordination of $\mathrm{Cu}(\mathrm{II})$ ion with thiosemicarbazones and one chloride ion suggests a distorted square planar geometry of complexes. All the compounds were screened against breast cancer (MCF-7 and MDA-MB231), skin cancer (A431) and normal prostate cell line (PNT2) in terms of cell viability and found that all the synthesized compounds exhibited in vitro antiproliferation toward the tested cancer cells. These complexes were found to be more effective on MDA-MB-231 than on A431 and MCF-7 cells. The molecule, CuL 1 was found to show a better anticancer potency compared to $\mathrm{CuL}_{2}$ as $\mathrm{CuL}_{1}$ was found to be less toxic to normal PNT2 cell line.

Keywords: Anticancer Potency, Copper(II) Complexes, Le Bail fitting, 5-Nitroisatin, Thiosemicarbazone
\end{abstract}

RASĀYAN J. Chem., Vol. 14, No.3, 2021

\section{INTRODUCTION}

Among the many principal causes of death, cancer crossed the data of death by heart disease in 2010. It will almost double globally by $2030 .{ }^{1}$ Lack of effective metal ions can cause many diseases such as heart disease in very young children due to the deficiency of copper, pernicious anemia due to cobalt deficiency, and growth retardation due to the deficiency of dietary zinc. ${ }^{2}$ Natural detoxication is a mechanism of medicinal or physiological eradication of toxic substances from the human body, which is performed by the liver. This type of mechanisms of metals attribute to design the different chelating compounds which can be used as anticancer agents toward various cancer cells lines with more potency and less toxicity. ${ }^{2}$

Platinum-based standard anticancer drugs viz. carboplatin, cisplatin, and oxaliplatin have great application against tumors, especially in testicular cancer (90\% success rate), ovarian, bladder, melanoma, SCLC (small cell lung cancer), NSCLC(non-small cell lung cancer), myelomas, and lymphomas. However, they have ineradicable limitations viz. critical side effects, common toxicity, and multifactorial drug resistance. $^{3}$ The in vitro and in vivo studies of many mononuclear and binuclear copper thiosemicarbazones complexes (Cu-TSCs) with distorted square planar or octahedral geometry have shown perfect anticancer activity toward various cancer cell lines. ${ }^{4}$ Copper(II) complexes, formed by coordination through the nitrogen atom of ligands viz. thiosemicarbazone, imidazole, benzohydroxamic acid, and purine have exhibited remarkable anticancer potency toward many cancers (Hep-G; human

Rasayan J. Chem., 14(3), 1600-1610(2021)

http://doi.org/10.31788/ RJC.2021.1436341

This work is licensed under a CC BY 4.0 license. 
RASĀYAN J. Chem.

Vol. 14 | No. 3 |1600-1610| July - September | 2021

hepatic, A-498; renal, and A-549; lung). ${ }^{5}$ Many copper(II) compounds (acetyl pridine thiosemicarbazone, pyridine carbaldehyde thiosemicarbazone etc.) were found to inhibit cancer cells much higher than that of their respective ligands as well as standard platinum drug (cisplatin) when these were tested against MCF7 (breast cancer), HeLa (immortal cervical cancer), HCT116 (colorectal cancer), A549 (lung adenocarcinoma), HepG2 (liver cancer), U937 (histiocytic lymphoma) etc. because of tending to cleave DNA (deoxyribonucleic acid) via different pathways (hydrolytic and oxidative) and apoptosis of cancer cell due to the generation of excess ROS (reactive oxygen species). ${ }^{6}$

Thiosemicarbazones, conferring special characteristics of mixed hard ( $\mathrm{N}$-atom) and soft ( $\mathrm{S}$-atom) donors, have significant heterogeneity in structural scaffolds and chelating ability with transition metals. These characteristics significantly contribute to the magnification of the biological activity of thiosemicarbazones as antitumor, antimicrobial, antiviral, antibacterial, and anti-parasitic agents that significantly increased coordination to metal ions. ${ }^{711}$ 5-Fluoro-2-pyridine formamide -4-pyrrolidinyl-3thiosemicarbazone exhibited significant anticancer activity toward MCF-7 cell $\left(\mathrm{IC}_{50} 0.9 \mu \mathrm{M}\right)$ by inhibiting anti-apoptotic protein Bcl-2, c-Jun, JNK (Jun N-terminal kinase), MAPK or MAP (mitogenactivated protein) kinase signaling and inducing intrinsic apoptotic pathways. ${ }^{12}$ Mechanisms of thiosemicarbazones (TSCs) as anticancer agent have been established: ROS generation, topoisomerase II inhibition, apoptotic induction, and RR (ribonucleotide reductase) inhibition that leads to the blockage of cell cycle synthesis phase and eventually apoptotic cell death. ${ }^{13}$

Research in isatin thiosemicarbazones gained pronounced interest after N-methyl isatin-3thiosemicarbazone (methisazone, also known as marboran) was reported active in the treatment of smallpox. ${ }^{14}$ Recently, copper complexes of N(4) modified thiosemicarbazones have been extensively studied for their anticancer potency toward various cancer cells because of low toxicity, wide spectrum of activity, non-resistance behavior and a novel mechanism of action as compared to that of platinum complexes. ${ }^{6,11,15}$ The above information made us enthusiastic in designing such type of thiosemicarbazones, their complexes and screening for their anti-proliferative potency.

\section{EXPERIMENTAL}

\section{Materials and Methods}

5-Nitroisatin, thiomorpholine, and N-methyl aniline were purchased from Alfa Aesar. Carbon disulphide (Qualigens fine chemicals), sodium chloroacetate (Chemical center, India), hydrazine hydrate, 98\% (Fisher scientific), dimethylamine (Sod Fine Chemical Limited, SDFL), acetonitrile (Merck), methyl alcohol (Fisher scientific), ethyl alcohol (Changshu Hongsheng fine chemical), diethyl ether (Merck), glacial acetic acid (Fisher scientific), concentrated hydrochloric acid (Merck), sodium hydroxide (Fisher Scientific), and copper(II) chloride (Merck) were used as obtained.

\section{Preparation of N(4)Substituted Thiosemicarbazones}

N(4) modified thiosemicarbazides; thiomorpholine-4-carbothiohydrazide (I) and N,Ndimethylhydrazinecarbothioamide (II) were prepared by using the procedure of J. P. Scovill through the formation of 2-((methyl(phenyl)carbamothioyl)thio)acetic acid and N-methyl-Nphenylhydrazinecarbothioamide. ${ }^{16}$

5-Nitroisatin-4-thiomorpholinyl-3-thiosemicarbazone, $\mathrm{L}_{1}$ and 5-nitroisatin -4, 4-dimethyl-3thiosemicarbazone, $\mathrm{L}_{2}$ were synthesized by refluxing the equimolar mixture of respective thiosemicarbazide $(0.35 \mathrm{~g}$ (I); $0.23 \mathrm{~g}$ (II), $2 \mathrm{mmol})$ and 5-nitroisatin $(0.38 \mathrm{~g}, 2 \mathrm{mmol})$ in absolute ethanol $(20 \mathrm{~mL})$ and glacial acetic acid $\left(4-5\right.$ drops) at $80^{\circ} \mathrm{C}$ for the duration of $6 \mathrm{~h}$ (Scheme-1). ${ }^{17}$ The refluxed product was allowed to cool at room temperature, washed with absolute alcohol during filtration and kept in the oven $\left(50^{\circ} \mathrm{C}\right)$ overnight to get the pure and dried product.

\section{Histtmpln $\left(\mathbf{L}_{1}\right)$}

Yield: $85 \%$; color: yellow-red; MP: $248^{\circ} \mathrm{C}$; anal. calc. for: $\mathrm{C}_{13} \mathrm{H}_{13} \mathrm{~N}_{5} \mathrm{O}_{3} \mathrm{~S}_{2}(351.40)$ : C, 44.43; $\mathrm{H}, 3.73 ; \mathrm{N}$, 19.93; found: $\mathrm{C}, 44.18 ; \mathrm{H}, 3.33 ; \mathrm{N}, 19.62 \%$. FTIR $(\mathrm{KBr}): \mathrm{v}, \mathrm{cm}^{-1}, 3170(\mathrm{H}-\mathrm{N}$; indole \& azomethine), $1693(\mathrm{C}=\mathrm{O}), 1619(\mathrm{C}=\mathrm{N}), 1336,790(\mathrm{C}=\mathrm{S}), 1113(\mathrm{~N}-\mathrm{N}) .{ }^{1} \mathrm{H}-\mathrm{NMR}: \delta$, ppm $12.94(\mathrm{~s}, 1 \mathrm{H}, \mathrm{HN}-\mathrm{C}=\mathrm{S}), 11.87$ 
RASĀYAN J. Chem.

Vol. 14 | No. 3 |1600-1610| July - September | 2021

(s, 1H, Indole-NH), 8.24 (s, 1H, C4-H), 8.13 (d, 1H,C6-H), 7.10 (d, 1H, C7-H), 4.27 (t, 4H, aliphatic$\mathrm{C} 11, \mathrm{C} 14-\mathrm{H}), 2.84$ (t, 4H, aliphatic-C12, C13-H), ${ }^{13} \mathrm{C}-\mathrm{NMR}: \delta$, ppm 179.65(C10), 163.24(C2), 147.23(C5), 143.16(C9), 132.41(C3), 127.23(C6), 121.06(C4), 115.53(C8), 111.80(C7), 53.56 (C11, C14), 26.83 (C12, C13). ESI-HRMS: $m / z$ [Found (calc.)]: 352.0532 (352.0533) $[\mathrm{M}+\mathrm{H}]^{+}, 374.0352$ (374.0351) $[\mathrm{M}+\mathrm{Na}]^{+}$. UV-Vis (DMSO, $\left.\lambda, \mathrm{nm}\right): 460,363$.

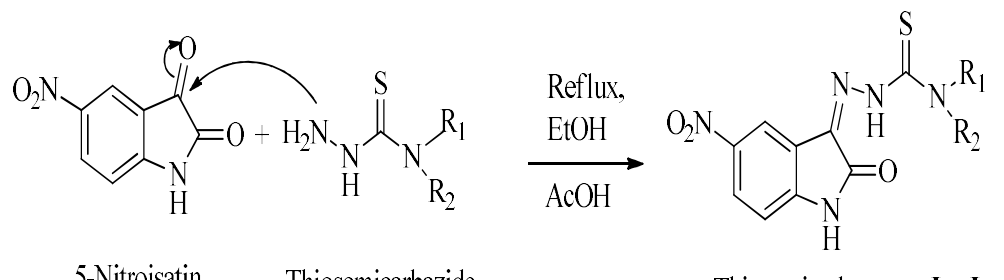

5-Nitroisatin Thiosemicarbazide Thiosemicarbazones, $\mathbf{L}_{1}, \mathbf{L}_{2}$

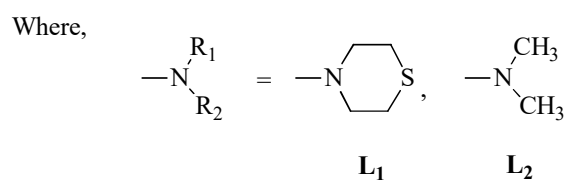

\section{$\operatorname{Histdma}\left(\mathbf{L}_{2}\right)$}

Scheme-1: Synthesis of N(4) Thiomorpholinyl/Dimethyl amine 5-Nitroisatin Thiosemicarbazones

Yield: 95\%; color: yellow; MP: 252-253 ${ }^{\circ} \mathrm{C}$; anal. calc. for: $\mathrm{C}_{11} \mathrm{H}_{11} \mathrm{~N}_{5} \mathrm{O}_{3} \mathrm{~S}$ (293.30): C, 45.04; $\mathrm{H}, 3.78$; N, 23.88; found: $\mathrm{C}, 44.98 ; \mathrm{H}, 3.65 ; \mathrm{N}, 23.69 \%$. FTIR (KBr): $v, \mathrm{~cm}^{-1}, 3232$ (H-N; indole \& azomethine), $1707(\mathrm{C}=\mathrm{O}), 1618(\mathrm{C}=\mathrm{N})$, 1317, $785(\mathrm{C}=\mathrm{S}), 1138(\mathrm{~N}-\mathrm{N}) .{ }^{1} \mathrm{H}-\mathrm{NMR}: \delta$, ppm $13.22(\mathrm{~s}, 1 \mathrm{H}, \mathrm{HN}-\mathrm{C}=\mathrm{S}), 11.93$ (s, 1H, Indole-NH), 8.30 (s, 1H,C4-H), 7.18 (d, 1H, C6-H), 7.16 (d, 1H,C7-H), 3.38 (s, 6H, aliphatic-C11, C12-H), ${ }^{13} \mathrm{C}-\mathrm{NMR}: \delta$, ppm 179.17(C10), 163.58(C2), 147.03(C5), 143.27(C9), 133.13(C3), 127.06(C6), 121.62(C4), 115.18(C8), 111.85(C7), 39.99 (C11, C12). ESI-HRMS: $m / z$ [Found (calc.)]: 294.0655 (294.0653) $[\mathrm{M}+\mathrm{H}]^{+}, 316.0474$ (316.0471) $[\mathrm{M}+\mathrm{Na}]^{+}$. UV-Vis (DMSO, $\left.\lambda, \mathrm{nm}\right): 453,360$.

\section{Preparation of Copper(II) Thiosemicarbazones}

Copper (II) thiosemicarbazones $\left(\mathrm{CuL}_{1}\right.$ and $\left.\mathrm{CuL}_{2}\right)$ were prepared by refluxing a mixture of $\mathrm{CuCl}_{2} \cdot 2 \mathrm{H}_{2} \mathrm{O}$ $(0.34 \mathrm{~g}, 2 \mathrm{mmol})$ and respective thiosemicarbazone $\left(0.70 \mathrm{~g}\left(\mathrm{~L}_{1}\right) ; 0.58 \mathrm{~g}\left(\mathrm{~L}_{2}\right), 2 \mathrm{mmol}\right)$ in absolute ethanol $(15 \mathrm{~mL})$ at $80^{\circ} \mathrm{C}$ for $6 \mathrm{~h}$ (Scheme-2). ${ }^{18}$ The resulting product was cooled at room temperature, filtered, washed subsequently with absolute alcohol and diethyl ether and dried in an oven at $50^{\circ} \mathrm{C}$. The dried product was further purified by recrystallization in absolute alcohol and again dried in an oven at $80^{\circ} \mathrm{C}$ for $2 \mathrm{~h}$.

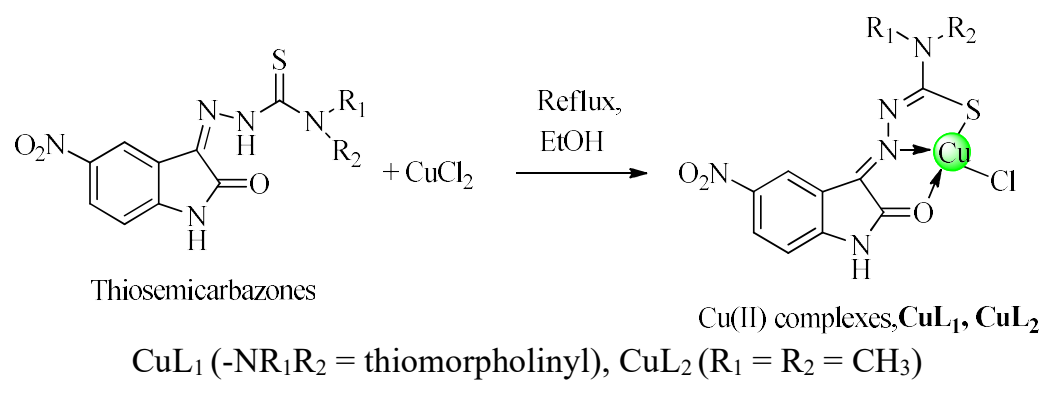

Scheme-2: Synthesis of N(4) thiomorpholinyl/dimethyl amine 5-nitroisatincopper(II) thiosemicarbazones

\section{[Cu(isttmpln) $\mathrm{Cl}]\left(\mathrm{CuL}_{1}\right)$}

Yield: $80 \%$; color: green-brown; MP: $>300^{\circ} \mathrm{C}$ (didn't decompose or melted up to $300^{\circ} \mathrm{C}$ ); anal. calc. for: $\mathrm{C}_{13} \mathrm{H}_{12} \mathrm{ClCuN}_{5} \mathrm{O}_{3} \mathrm{~S}_{2}$ (449.40): C, 34.74; H, 2.69; N, 15.58; found: $\mathrm{C}, 34.78 ; \mathrm{H}, 2.76 ; \mathrm{N}, 15.36 \%$. FTIR $(\mathrm{KBr}): v, \mathrm{~cm}^{-1} 3111(\mathrm{H}-\mathrm{N}$; indole $), 1585(\mathrm{C}=\mathrm{O}), 1561(\mathrm{C}=\mathrm{N}), 1311,773(\mathrm{C}=\mathrm{S}), 1127(\mathrm{~N}-\mathrm{N})$. ESI-HRMS: $m / z$ [Found (calc.)]: 470.9258 (470.9257) $[\mathrm{M}+\mathrm{Na}]^{+}$. UV-Vis (DMSO, $\lambda, \mathrm{nm}$ ): 447, 360, 308. EPR: $\mathrm{g}=$ 2.123 . 
RASĀYAN J. Chem.

Vol. 14 | No. 3 |1600-1610| July - September | 2021

\section{$[\mathrm{Cu}(\mathrm{istdma}) \mathrm{Cl}]\left(\mathrm{CuL}_{2}\right)$}

Yield: $71 \%$; color: green-brown; MP: $>300^{\circ} \mathrm{C}$ (didn't decompose or melted up to $300^{\circ} \mathrm{C}$ ); anal. calc. for: $\mathrm{C}_{11} \mathrm{H}_{10} \mathrm{ClCuN}_{5} \mathrm{O}_{3} \mathrm{~S}$ (391.29): C, 33.76; H, 2.58; N, 17.90; found: $\mathrm{C}, 33.85 ; \mathrm{H}, 2.64 ; \mathrm{N}, 17.59 \%$. FTIR $(\mathrm{KBr}): v, \mathrm{~cm}^{-1} 3105(\mathrm{H}-\mathrm{N}$; indole), $1664(\mathrm{C}=\mathrm{O}), 1598(\mathrm{C}=\mathrm{N})$, 1255, $746(\mathrm{C}=\mathrm{S}), 1148(\mathrm{~N}-\mathrm{N})$. ESI-HRMS: $m / z$ [Found (calc.)]: 412.9381 (412.9379) $[\mathrm{M}+\mathrm{Na}]^{+}$. UV-Vis (DMSO, $\left.\lambda, \mathrm{nm}\right): 433,362$. EPR: $\mathrm{g}_{\|}=2.200$, $\mathrm{g}_{\perp}=2.060, \mathrm{~g}=2.106, \mathrm{G}=3.426$.

\section{Instruments}

Philip Harris, a melting point apparatus, was used to record the melting point of the compounds. PerkinElmer CHN-2400 (IIT Madras, India) and Thermo Finnigan elemental analyzer (Savitribai Phule Pune University (SPPU), India) were used for CHN analysis of ligands and complexes respectively. FTIR (FTIR spectrophotometer; tensor- 37, optical bench detector, $4 \mathrm{~cm}^{-1}$ resolution, Pt-ATR and 4000 to 400 $\mathrm{cm}^{-1}$ ), NMR (Bruker advance III HD NMR spectrometer, $400 \mathrm{MHz}$, DMSO- $d_{6}$, room temperature), ESIHRMS (Mass spectrometer; Bruker IMPACT HD liquid chromatography, CIF, SPPU), UV-vis. (SHIMADZU UV-spectrophotometer, UV-1800, 700-250 nm, DMSO solution; $25 \mu \mathrm{M}$ ), and TGA (Thermal analyzer-SDT 650 , DSC/TGA system, $\mathrm{N}_{2}$ atmosphere, temperature range $20-800^{\circ} \mathrm{C}$, heating

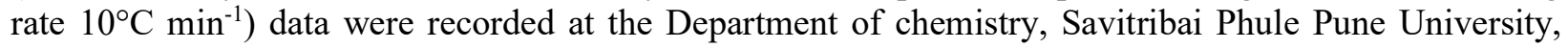
India. PXRD (Bruker diffractometer; D8 Discover, high resolution, point detector of scintillation counter, monochromatized $\mathrm{Cu} \mathrm{K} \alpha 1$ radiation, scan rate $1.0 \mathrm{~second} / \mathrm{step}$ and step size $0.02^{\circ}$ at $298 \mathrm{~K}, 2 \theta=10^{\circ}-80^{\circ}$ ) and EPR (Bruker biospin corp. (EMX series) Model: A 200-9.5/12B/S) data were recorded at NAST (Nepal Academy of Science and Technology) Nepal and Sogang University, Seoul, Korea respectively.

\section{Cell Lines and Culture Conditions}

The synthesized compounds were screened against cancer cell lines; MCF-7, MDA-MB-231, A431 and) normal prostate cell line (PNT2) for their anticancer potential in terms of viability at the faculty of Life Science and Biotechnology, South Asian University, New Delhi, India and inhibition percentage was determined from the data of percentage viability. The cancer as well as non-cancer cells were grown in Dulbecco's Modified Eagle Medium (DMEM) and the atmosphere (incubator) was maintained at $37^{\circ} \mathrm{C}$ with $5 \% \mathrm{CO}_{2}$ and $95 \%$ air for $72 \mathrm{~h}$.

\section{Methods for Anticancer Screening}

Anticancer screening of the synthesized compounds was carried out through the methods given below mentioned in our published paper. ${ }^{11}$

\section{Seeding of the Cells}

A diluted cell suspension containing 3000 cells $/ 100 \mu \mathrm{L}$ was prepared in a falcon tube and resuspended properly using the pipette so that the cells do not settle at the bottom. The falcon tube containing cells was constantly swirled gently throughout the inoculation of $100 \mu \mathrm{L}$ of cell suspension in each of the wells in 96 well plates. The plate was shaken mildly up down and sideways and slight tapping was done. It was observed in a microscope and kept in an incubator for $24 \mathrm{~h}$. Seeding of the cells (MCF-7, MDA-MB-231, A431 and PNT2) was done by using the above procedure.

\section{Cell Viability Assay}

The media was removed using the multichannel pipette and the cells were washed with 90-100 $\mu \mathrm{L}$ PBS (phosphate saline buffer). It was kept in the rocker for 5 min after which PBS was removed. Then, $50 \mu \mathrm{L}$ of crystal violet $(0.5 \%)$ was added. The plate was incubated in the rocking at a frequency of 20 oscillations/min for $30 \mathrm{~min}$. It was washed three times in the beaker full of water. The crystal violet in excess was then discarded by jerking. It was dried by patting in tissue paper. Then it was left overnight to dry to remove all moisture. Methyl alcohol $(200 \mu \mathrm{L})$ was added to each well and then the plate was kept on bench rocker for $30 \mathrm{~min}$ at $25^{\circ} \mathrm{C}$. The microplate reader was used to measure the optical density at 570 $\mathrm{nm}$ and count cell viability. The results are the mean value of four independent experimental 
RASĀYAN J. Chem.

Vol. 14 | No. 3 |1600-1610| July - September | 2021

measurements carried out in similar conditions using standard deviation and the values were plotted graphically.

\section{RESULTS AND DISCUSSION}

\section{IR Studies}

In the synthesized compounds, the broad symmetrical stretching band in the region $3232-3170 \mathrm{~cm}^{-1}$ assigned to $v(\mathrm{~N}-\mathrm{H})$ of indole and azomethine moieties of thiosemicarbazones and appeared at the lower energy region, 3111-3105 $\mathrm{cm}^{-1}$ as an indole $\mathrm{N}-\mathrm{H}$ because azomethine $\mathrm{N}-\mathrm{H}$ deprotonated during the coordination of ligands to copper(II) ion $\left(\mathrm{CuL}_{1}\right.$ and $\left.\mathrm{CuL}_{2}\right) \cdot{ }^{17,19}$ The non-existence of stretching band at about $2570 \mathrm{~cm}^{-1}$, specific to $v(\mathrm{~S}-\mathrm{H})$ and the existence of two strong bands at $1336-1317 \mathrm{~cm}^{-1}$, and 790 $785 \mathrm{~cm}^{-1}$, specific to $v(\mathrm{C}=\mathrm{S})$ confirmed the existence of solid thiosemicarbazones $\left(\mathrm{L}_{1}\right.$ and $\left.\mathrm{L}_{2}\right)$ in the thione tautomeric form. ${ }^{19-22}$ Bands appeared in uncomplexed thiosemicarbazones $\left(\mathrm{L}_{1}\right.$ and $\left.\mathrm{L}_{2}\right)$ showed downward shift of $v(\mathrm{C}=\mathrm{S})$ in their respective copper(II) complexes due to the coordination of sulphur in thiol tautomeric form and the deprotonation at $\mathrm{H}-\mathrm{N}-\mathrm{C}=\mathrm{S}$ group and hence observed at the lower energy region $1311-1255 \mathrm{~cm}^{-1}$ and $773-746 \mathrm{~cm}^{-1} \cdot{ }^{23}$ In the thiosemicarbazone $\mathrm{L}_{1}$, strong stretching bands appeared at $1693 \mathrm{~cm}^{-1}$ and $1619 \mathrm{~cm}^{-1}$ assigned to $v(\mathrm{C}=\mathrm{O})$ and $v(\mathrm{C}=\mathrm{N})$ of thiosemicarbazone respectively. ${ }^{9-11}$ The coordination of ligand $\mathrm{L}_{1}$ to copper(II) ion $\left(\mathrm{CuL}_{1}\right)$ shifted the $v(\mathrm{C}=\mathrm{O})$ and $v(\mathrm{C}=\mathrm{N})$ bands at $1585 \mathrm{~cm}^{-1}$ and $1561 \mathrm{~cm}^{-1}$ respectively. Similarly, two strong stretching bands of ligand $\mathrm{L}_{2}$ at $1707 \mathrm{~cm}^{-1}$ and $1618 \mathrm{~cm}^{-}$ ${ }^{1}$ specific to $v(\mathrm{C}=\mathrm{O})$ and $v(\mathrm{C}=\mathrm{N})$ respectively shifted towards the lower energy $1664 \mathrm{~cm}^{-1}$ and $1598 \mathrm{~cm}^{-1}$ thereby indicating their coordination to copper(II) ion $\left(\mathrm{CuL}_{2}\right) \cdot{ }^{19,22}$ The different mode of band shift in these complexes may arise due to the different substituents at $\mathrm{N}(4)$ position such as cyclic thiomorpholinyl and dimethyl amine groups. The strong bands appeared at $1138-1113 \mathrm{~cm}^{-1}$ assigned to $v(\mathrm{~N}-\mathrm{N})$ frequencies of thiosemicarbazones. ${ }^{20,23}$ The coordination of ligands $\left(\mathrm{L}_{1}\right.$ and $\left.\mathrm{L}_{2}\right)$ to metal ion showed the positive shift of $v(\mathrm{~N}-\mathrm{N})$ band $\left(1148-1127 \mathrm{~cm}^{-1}\right)\left(\mathrm{CuL}_{1}\right.$ and $\left.\mathrm{CuL}_{2}\right)$, thereby confirming the formation of $\pi$ bond in thioamide nitrogen atoms during coordination. ${ }^{20,23}$ The shift in the position of $v(\mathrm{C}=\mathrm{S}), v(\mathrm{C}=\mathrm{O})$, and $v(\mathrm{C}=\mathrm{N})$ bands of thiosemicarbazones to lower energy region in the complexes confirm the chelation of terdentate thiosemicarbazones to copper(II) ion thereby indicating the existence of complexes in distorted square planar geometry where one site is occupied by chloride ion.

\section{NMR Studies}

In ${ }^{1} \mathrm{H}-\mathrm{NMR}$ (DMSO- $d_{6}$ ) spectra of $\mathrm{N}(4)$ substituted thiosemicarbazones (Fig.-1) the signals of highly polar $\mathrm{H}-\mathrm{N}-\mathrm{C}=\mathrm{S}$ and indol-NH protons were observed downfield as a singlet at 13.22-12.94 ppm and 11.93-11.87 ppm, respectively. ${ }^{21,24,25}$ The thiosemicarbazones $\left(\mathrm{L}_{1}\right.$ and $\left.\mathrm{L}_{2}\right)$ having no peaks at 4 ppm specific to thiol proton also showed their existence in thione tautomeric form. ${ }^{26,27}$ All the aromatic protons of isatin moiety were seen as singlet or doublet signals at 8.30 to $7.10 \mathrm{ppm} .{ }^{21}$ In the case of N(4) thiomorpholinyl group, the signals of $-\mathrm{CH}_{2}$ - protons were found as a multiplet at $4.27-2.84 \mathrm{ppm}^{19}$ and that of $\mathrm{N}(4)$ methyl protons were observed as a singlet at $3.38 \mathrm{ppm} .{ }^{22}$

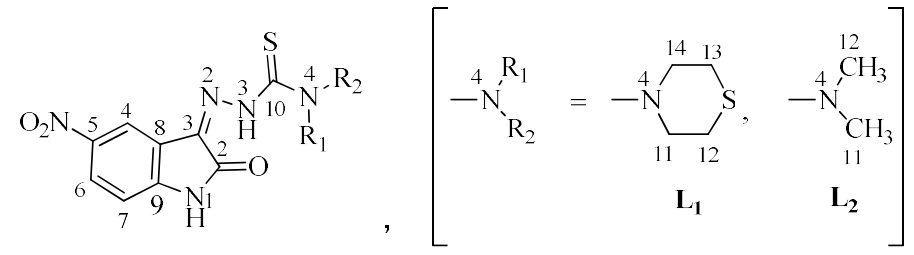

Fig.-1: Structure of N(4) thiomorpholinyl/dimethyl amine 5-nitroisatinThiosemicarbazones

${ }^{13} \mathrm{C}-\mathrm{NMR}$ spectra for chemically nonequivalent, thiocarbonyl $(\mathrm{C}=\mathrm{S})$, carbonyl $(\mathrm{C}=\mathrm{O})$ and azomethine $(\mathrm{C}=\mathrm{N})$ carbon atoms of thiosemicarbazones $\left(\mathrm{L}_{1}\right.$ and $\left.\mathrm{L}_{2}\right)$ showed the signals toward downfield region $179.65-179.17,163.58-163.24$ and $133.13-132.41 \mathrm{ppm}$, respectively. ${ }^{21,28,29}$ The signals for aromatic carbon atoms were present in the range, $147.23-111.80 \mathrm{ppm}^{21,22,24}$ The signals of N(4) thiomorpholinyl carbon atoms were seen at 53.56-26.83 $\mathrm{ppm}^{19}$ and that of $\mathrm{N}(4)$ dimethyl carbon atom was embedded with solvent peak. In the synthesized thiosemicarbazones, the chemical shift values of all protons and carbons were seen in the region as expected in their proposed structures.

1604 
RASĀYAN J. Chem.

Vol. 14 | No. 3 |1600-1610| July - September | 2021

\section{ESI-HRMS Studies}

ESI-HRMS is a technique that generates ions from the aerosol using an electrospray with high voltage to a liquid. This technique is used to determine the high accuracy chemical masses ( $4^{\text {th }}$ decimal places). The ESI-HRMS measurements for the mass spectral peaks of the synthesized compounds $\left(\mathrm{L}_{1}, \mathrm{~L}_{2}, \mathrm{CuL}_{1}\right.$ and $\mathrm{CuL}_{2}$ ) were recorded using the positive mode to observe the protonated and alkali adduct analyte molecules. The protonated molecular ion $[\mathrm{M}+\mathrm{H}]^{+}$peaks obtained from thiosemicarbazones were $\mathrm{m} / z=$ 352.0532 (calc., 352.0533$)\left(\mathrm{L}_{1}\right)$, and $m / z=294.0655$ (calc., 294.0653) $\left(\mathrm{L}_{2}\right) .{ }^{19,30}$ Beside protonated peaks, the thiosemicarbazones showed the molecular ion $[\mathrm{M}+\mathrm{Na}]^{+}$peaks: $m / z=374.0352$ (calc., 374.0351$)\left(\mathrm{L}_{1}\right)$ and $m / z=316.0474$ (calc., 316.0471) $\left(\mathrm{L}_{2}\right) .{ }^{31,32}$ The appearance of other significant peaks: $\mathrm{m} / \mathrm{z} ; 146.0084$ (calc., 146.0098) and $\mathrm{m} / z ; 116.0050$ (calc., 116.0529) exhibited the presence of fragments: $\mathrm{N}(4)$ thiomorpholinyl with thiocarbonyl group $\left[\mathrm{C}_{5} \mathrm{H}_{8} \mathrm{NS}_{2}\right]^{+}$and that of $\mathrm{N}(4)$ thiomorpholinyl with carbon $\left[\mathrm{C}_{5} \mathrm{H}_{8} \mathrm{NS}+2 \mathrm{H}\right]^{++}$ions respectively arising from the thermal cleavage of the ligand $\mathrm{L}_{1 .}{ }^{29,33}$ In the ligand $\mathrm{L}_{2}$, the peak at $m / z ; 88.0213$ (calc., 88.0221) was observed due to the presence of fragment, $\mathrm{N}(4)$ dimethyl with thiocarbonyl group $\left[\mathrm{C}_{3} \mathrm{H}_{6} \mathrm{NS}\right]^{+}$ion. ${ }^{29,33}$ The molecular ion $[\mathrm{M}+\mathrm{Na}]^{+}$peaks of the complexes $\left(\mathrm{CuL}_{1}\right.$ and $\mathrm{CuL}_{2}$ ) have been recorded as follows: $m / z ; 470.9258$ (calc., 470.9257 ) $\left(\mathrm{CuL}_{1}\right), \mathrm{m} / z ; 412.9381$ (calc., 412.9379) $\left(\mathrm{CuL}_{2}\right){ }^{19,32} \mathrm{In} \mathrm{CuL}_{1}, \mathrm{~m} / \mathrm{z} ; 490.9816$ (calc., 490.9366) is assigned for $[\mathrm{M}+\mathrm{K}]^{+}$ion having ${ }^{65} \mathrm{Cu}$ and ${ }^{41} \mathrm{~K}$ isotopes. ${ }^{31}$ Like that in ligand $\mathrm{L}_{1}$, the complex $\mathrm{CuL}_{1}$ also showed the same fragments peaks: $\mathrm{m} / z$; 146.0084 (calc., 146.0098) $\left[\mathrm{C}_{5} \mathrm{H}_{8} \mathrm{NS}_{2}\right]^{+}$and $\mathrm{m} / z$; 116.0050 (calc., 116.0529) $\left[\mathrm{C}_{5} \mathrm{H}_{8} \mathrm{NS}+2 \mathrm{H}\right]^{++} .^{29}$ The copper has two isotopes viz. ${ }^{63} \mathrm{Cu}$ and ${ }^{65} \mathrm{Cu}$ so, a supplementary peak, has been seen at the position adjacent to molecular ion $[\mathrm{M}+\mathrm{Na}]^{+}$peak of $\mathrm{Cu}$ (II) complexes. The mass spectral data of the ligands and their $\mathrm{Cu}(\mathrm{II})$ complexes match well with the ones calculated for their proposed structures.

\section{UV-Visible Studies}

The UV-Vis data of the synthesized compounds were measured at $700-250 \mathrm{~nm}$ in DMSO solution $(25 \mu \mathrm{M})$. The bands with shoulder-like extensions at $360 \mathrm{~nm}$ assigned to $\mathrm{n} \rightarrow \pi^{*}$ intraligand transitions, mainly due to carbonyl $(>\mathrm{C}=\mathrm{O})$ group of isatin moiety and azomethine $(\mathrm{C}=\mathrm{N})$ of thiosemicarbazones $\left(\mathrm{L}_{1}\right.$ and $\left.\mathrm{L}_{2}\right){ }^{33,34}$ The coordination of thiosemicarbazones to $\mathrm{Cu}(\mathrm{II})$ ion shifted these bands slightly toward lower wavelength in the complexes $\left(\mathrm{CuL}_{1}\right)$ and $\left(\mathrm{CuL}_{2}\right){ }^{33,34}$ The slight variation in the $\mathrm{n} \rightarrow \pi^{*}$ electronic transitions and presence of an additional band at $308 \mathrm{~nm}$ in $\mathrm{CuL}_{1}$ complex may arise due to the different nature of $\mathrm{N}(4)$ substituents $\left(\mathrm{CuL}_{1}\right.$; cyclic and $\mathrm{CuL}_{2}$; acyclic). A second $\mathrm{n} \rightarrow \pi^{*}$ electronic transition bands in the lower energy region $(460-453 \mathrm{~nm}$ ) were also observed in the thiosemicarbazones originating from their thioamide functions. ${ }^{34}$ These spectral bands of thiosemicarbazones also shifted to lower wavelength in their respective complexes and merged with the band of higher energy due to $n \rightarrow \pi^{*}$ electronic transitions ${ }^{34,35}$ In the complexes, high-intensity absorption bands were seen at $447 \mathrm{~nm}\left(\mathrm{CuL}_{1}\right)$ and $433 \mathrm{~nm}$ $\left(\mathrm{CuL}_{2}\right)$ as a result of intraligand electronic transitions and LMCT (ligand to metal charge transfer) from $\mathrm{S}^{-}$ to $\mathrm{Cu}^{2+}$ ion. ${ }^{34,36,37}$ The positive shift of bands in metal complexes may be arisen owing to the comparatively loss of hydrogen bonding with solvent. ${ }^{34}$ Being weak field ligands, the thiosemicarbazones caused a transition metal to have a small crystal field splitting with high spin, so the complexes did not exhibit d-d transition band at higher wavelength or may be merged with the appeared broad bands or suppressed due to solvent effect of dimethyl sulphoxide (DMSO). ${ }^{31}$

\section{Thermal Studies}

The thermal decompositions of copper (II) complexes were studied under nitrogen atmosphere by thermogravimetry (TG) at $20-800^{\circ} \mathrm{C}$ and significant mass losses are presented in Table-1. Both the compounds $\left(\mathrm{CuL}_{1}\right.$ and $\left.\mathrm{CuL}_{2}\right)$ showed almost the same thermal behavior. The thermal gravimetric analysis (TGA) pattern of $\mathrm{Cu}$ (II) complexes are endothermic. ${ }^{38,39}$ The weight loss at the initial stage of TG analysis in the range of $30-250^{\circ} \mathrm{C}$ usually occurs due to evaporation and dehydration of surface and adsorbed water from the complex materials. ${ }^{40}$ The synthesized copper (II) complexes, stable to air at room temperature, were found anhydrous because they did not show decomposition peaks up to $150^{\circ} \mathrm{C} .{ }^{41} \mathrm{In}$ complex $\mathrm{CuL}_{1}$, the endothermic peaks appeared as a result of organic part decomposition at 226.03, 
RASĀYAN J. Chem.

Vol. 14 | No. 3 |1600-1610| July - September | 2021

$343.31,364.81$ and $500.22^{\circ} \mathrm{C}$ assigned to the loss of $\mathrm{C}_{5} \mathrm{H}_{8} \mathrm{NS}$ (found/calc. 25.45/25.40\%), $\mathrm{CN}_{2} \mathrm{~S}$ (found/calc. 15.94/16.04 \%), $\mathrm{NO}_{2}$ (found/calc. 10.14/10.23\%) and $\mathrm{C}_{2} \mathrm{HNO}$ (found/calc. 12.71/12.24 \%) respectively. ${ }^{42}$

The complex, $\mathrm{CuL}_{2}$, also exhibited endothermic peaks as a result of organic part decomposition at 240.95, $278.98,320.21,368.19$ and $515.14^{\circ} \mathrm{C}$ are attributed to the loss of $\mathrm{NH}$ (found/calc. 3.66/3.83\%), $\mathrm{NO}_{2} \mathrm{~S}$ (found/calc. 20.46/19.93\%), Cl (found/ calc. 8.84/9.05\%), $\mathrm{C}_{3} \mathrm{H}_{6} \mathrm{~N}$ (found/ calc. 14.66/14.33\%) and $\mathrm{N}_{2} \mathrm{O}$ (found/ calc. 11.42/11.24\%) respectively. ${ }^{42,43}$ The cupric oxide $(\mathrm{CuO})$ was obtained as a residue at $715.05^{\circ} \mathrm{C}\left(\mathrm{CuL}_{1}\right)$ and $721.63^{\circ} \mathrm{C}\left(\mathrm{CuL}_{2}\right) .^{44}$

\begin{tabular}{|c|c|c|c|c|c|}
\hline \multicolumn{6}{|c|}{ Table-1: Thermal Decomposition Data of $\mathrm{Cu}$ (II) Complexes of Thiosemicarbazones } \\
\hline Compounds & Stage & $\begin{array}{c}\text { Peak } \\
\text { Temperature in } \\
\text { TGA }\left({ }^{\circ} \mathrm{C}\right)\end{array}$ & $\begin{array}{c}\text { TGA Mass } \\
\text { Loss }(\%)\end{array}$ & $\begin{array}{c}\text { Theoretical } \\
\text { Mass Loss (\%) }\end{array}$ & $\begin{array}{c}\text { Fraction } \\
\text { Loss/Residue }\end{array}$ \\
\hline \multirow[t]{3}{*}{$\mathrm{CuL}_{1}$} & First & $\begin{array}{l}226.03 \\
343.31 \\
\end{array}$ & $\begin{array}{l}25.45 \\
15.94 \\
\end{array}$ & $\begin{array}{l}25.40 \\
16.04 \\
\end{array}$ & $\begin{array}{c}\mathrm{C}_{5} \mathrm{H}_{8} \mathrm{NS} \\
\mathrm{CN}_{2} \mathrm{~S} \\
\end{array}$ \\
\hline & Second & $\begin{array}{l}364.81 \\
500.22 \\
\end{array}$ & $\begin{array}{l}10.14 \\
12.71 \\
\end{array}$ & $\begin{array}{l}10.23 \\
12.24\end{array}$ & $\begin{array}{c}\mathrm{NO}_{2}, \\
\mathrm{C}_{2} \mathrm{HNO} \\
\end{array}$ \\
\hline & Third & 715.05 & - & - & $\mathrm{CuO}$ as residue \\
\hline \multirow[t]{4}{*}{$\mathrm{CuL}_{2}$} & First & 240.95 & 3.66 & 3.83 & $\mathrm{NH}$ \\
\hline & Second & $\begin{array}{l}278.98 \\
320.21 \\
\end{array}$ & $\begin{array}{c}20.46 \\
8.84 \\
\end{array}$ & $\begin{array}{c}19.93 \\
9.05 \\
\end{array}$ & $\begin{array}{c}\mathrm{NO}_{2} \mathrm{~S} \\
\mathrm{Cl}\end{array}$ \\
\hline & Third & $\begin{array}{l}368.19 \\
401.06 \\
515.14 \\
\end{array}$ & $\begin{array}{c}14.66 \\
6.68 \\
11.42 \\
\end{array}$ & $\begin{array}{c}14.33 \\
- \\
11.24 \\
\end{array}$ & $\begin{array}{c}\mathrm{C}_{3} \mathrm{H}_{6} \mathrm{~N} \\
- \\
\mathrm{N}_{2} \mathrm{O} \\
\end{array}$ \\
\hline & Fourth & 721.63 & - & - & $\mathrm{CuO}$ as residue \\
\hline
\end{tabular}

\section{PXRD Studies}

Single crystals of $\mathrm{Cu}$ (II) thiosemicarbazone complexes $\left(\mathrm{CuL}_{1}\right.$ and $\left.\mathrm{CuL}_{2}\right)$ could not be developed. Thus PXRD diffraction patterns for these complexes were obtained by using high-resolution powder X-ray instrument. Le Bail fitting is (an important technique for the extraction of intensities and refinement of the unit cell of complexes). ${ }^{45,46}$ The Le Bail fitting of observed powder X-ray pattern of these copper(II) complexes of thiosemicarbazones was carried out by taking crystal lattice parameters of analogous copper(II) thiosemicarbazone complexes of CCDC no. 1864662. ${ }^{19}$ The Le Bail fitting of those copper(II) complexes; $\mathrm{CuL}_{1}$ and $\mathrm{CuL}_{2}$ suggests the monoclinic symmetry with the space group $P 12_{1} 1$ as shown in Fig.-2 and Fig.-3 respectively. The PXRD pattern confirmed that both thiosemicarbazone copper(II) complexes $\left(\mathrm{CuL}_{1}\right.$ and $\left.\mathrm{CuL}_{2}\right)$ have distorted square planar geometry ${ }^{47,48}$ coordinated with terdentate thiosemicarbazone anion and one chloride ion. The Le Bail fitting lattice parameter for the complexes are summarized in Table-2.

Table-2: Le Bail Fitting Lattice Constants of the Complexes; $\mathrm{CuL}_{1}$ and $\mathrm{CuL}_{2}$.

\begin{tabular}{c|c|c}
\hline Parameter & $\mathrm{CuL}_{1}$ & $\mathrm{CuL}_{2}$ \\
\hline Crystal system & Monoclinic & Monoclinic \\
\hline Space group & $P 12_{1} 1$ & $P 12_{1} 1$ \\
\hline$a$ & 8.45737 & 8.40516 \\
\hline$b$ & 23.05949 & 22.53728 \\
\hline$c$ & 10.14290 & 10.29506 \\
\hline$\alpha$ & 90.00000 & 90.0000 \\
\hline$\beta$ & 97.15483 & 98.68017 \\
\hline$\gamma$ & 90.00000 & 90.0000 \\
\hline \multicolumn{2}{|c|}{$\left(\right.$ Note: The parameter a, b, c are in $\AA$ and $\alpha, \beta, \gamma$ are in ${ }^{\circ}$ ) }
\end{tabular}

\section{EPR Studies}

The solid-state EPR spectra of the synthesized complexes $\left(\mathrm{CuL}_{1}\right.$ and $\left.\mathrm{CuL}_{2}\right)$ have been used to obtain structural information, especially the coordination environment in metal complexes. The spectral data, recorded at room temperature, showed that $\mathrm{CuL}_{1}$, conferring dipolar interaction and escalated spin-lattice 
RASĀYAN J. Chem.

Vol. 14 | No. 3 |1600-1610| July - September | 2021

relaxation has isotropic symmetry (i.e. $\mathrm{g}_{\mathrm{x}}=\mathrm{g}_{\mathrm{y}}=\mathrm{g}_{\mathrm{z}}=2.123$ ) but $\mathrm{CuL}_{2}$ displays axial signal with two $\mathrm{g}$ values $\left(g_{l}>g_{\perp}\right) .{ }^{49,50}$ Comparatively lower value of $g$ is related with stronger coordination and significant covalency as a consequence of $\mathrm{O}$ and $\mathrm{S}$ donor atoms in the coordination sphere as well as the small effect of spin-orbit coupling in the parallel direction. ${ }^{49,51}$ Lower value of $g_{\mid}$also suggests less interaction with neighbouring centers. ${ }^{49,51}$ The absence of four hyperfine structures in both compounds may be due to line broadening which causes by incomplete separation of paramagnetic centers. ${ }^{40,52}$

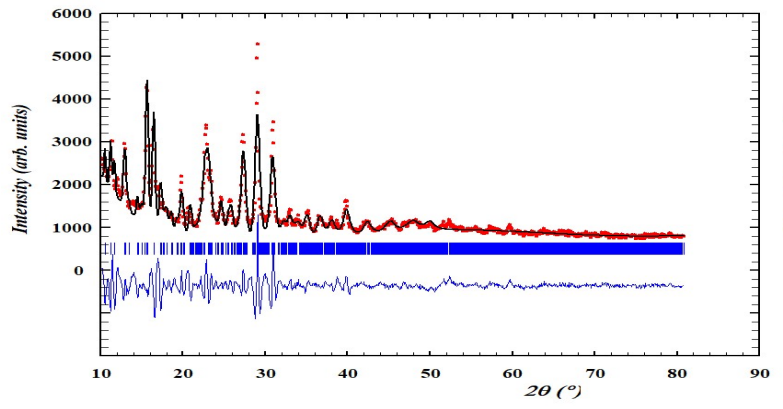

Fig.-2: Le Bail Fitting of $\mathrm{CuL}_{1}$ Complex

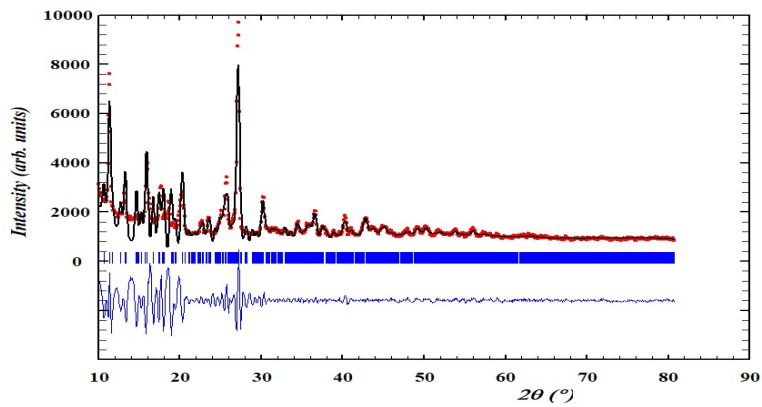

Fig.-3: Le Bail Fitting of $\mathrm{CuL}_{2}$ Complex

The $\mathrm{g}_{\mathrm{I}}$ of 2.2 and $\mathrm{g}_{\perp} \sim 2.0$ indicate that the coordination of copper(II) ion through ligands possess distorted square planar geometry. ${ }^{53,54}$ Distorted square planar geometry is further supported by other spectroscopic data in line with the EPR spectra.

The copper (II) complexes having $\mathrm{g}_{\|}(<2.3)$ suggest a large percentage of covalency in L-M (ligand-metal) bonding. In $\mathrm{CuL}_{2}$, the trend $\mathrm{g}_{\mid}>\mathrm{g}_{\perp}>2.0023\left(\mathrm{~g}_{\mathrm{e}}\right)$, and $\mathrm{G}=\left(\mathrm{g}_{\mid}-2\right) /\left(\mathrm{g}_{\perp}-2\right)<4.4$ correspond to the presence of unpaired electron of $\mathrm{Cu}(\mathrm{II})$ in $\mathrm{dx}^{2}-\mathrm{y}^{2}$ ground state with small exchange coupling values ${ }^{55,56}$ Further $\mathrm{g}_{\mathrm{I}}$ values are close to the complexes indicating similar nature of bonding.

\section{Anticancer Activity}

As it is marked from Table-3 and Table-4, all the synthesized compounds showed high cell inhibitory effects toward cancer cells viz. MDA-MB-231, MCF-7 and A431.

Table-3: Cell Viability $(\mu \mathrm{M})$ toward Different Cancer Cells for $72 \mathrm{~h}$

\begin{tabular}{c|c|c|c|c}
\hline \multirow{2}{*}{ Compounds } & \multicolumn{4}{|c}{ Cell Viability } \\
\cline { 2 - 5 } & MCF-7 & MDA-MB-231 & A431 & PNT2 \\
\hline $\mathrm{L}_{1}$ & $0.59 \pm 0.29$ & $0.45 \pm 0.04$ & $0.65 \pm 0.04$ & $0.39 \pm 0.04$ \\
\hline $\mathrm{L}_{2}$ & $0.58 \pm 0.12$ & $0.41 \pm 0.09$ & $0.58 \pm 0.19$ & $0.49 \pm 0.06$ \\
\hline $\mathrm{CuL}_{1}$ & $0.64 \pm 0.16$ & $0.28 \pm 0.05$ & $1.00 \pm 0.16$ & $0.60 \pm 0.04$ \\
\hline $\mathrm{CuL}_{2}$ & $0.62 \pm 0.13$ & $0.31 \pm 0.04$ & $0.65 \pm 0.12$ & $0.27 \pm 0.009$ \\
\hline $\mathrm{DMSO}$ & 1.00 & 1.00 & 1.00 & 1.00 \\
\hline
\end{tabular}

Table-4: Cell Inhibition against Various Cancer Cells for $72 \mathrm{~h}$.

Anticancer Activity $\left(\mathrm{IC}_{50} \mu \mathrm{M}\right)$

\begin{tabular}{|c|c|c|c|c|}
\hline Compounds & MCF-7 & MDA-MB-231 & A431 & PNT2 \\
\hline $\mathrm{L}_{1}$ & 1.53 & 0.71 & 1.34 & 0.38 \\
\hline $\mathrm{L}_{2}$ & 1.65 & 0.97 & 1.41 & 0.46 \\
\hline $\mathrm{CuL}_{1}$ & 1.68 & 0.32 & 2.05 & 0.58 \\
\hline $\mathrm{CuL}_{2}$ & 1.63 & 0.33 & 1.33 & 0.27 \\
\hline Control (DMSO) & $2.60-2.85$ & $1.74-2.32$ & $2.04-2.42$ & $0.94-0.96$ \\
\hline
\end{tabular}

The copper (II) complexes contributed to reduce the cell viability (\%) for MDA-MB-231 cells, however showed less effect on A431 and MCF-7 cells. The molecule, $\mathrm{CuL}_{1}$ showed better anticancer potency (MDA-MB-231) compared to $\mathrm{CuL}_{2}$ as $\mathrm{CuL}_{1}$ showed less anti-proliferative activity on PNT2 (normal prostate epithelium immortalized with SV40) cell line. The reduction of copper(II) to copper(I) due to the lack of blood vessel and low oxygen supply of tumors offers the copper compounds for medicinal opportunity to target tumor cells. ${ }^{57}$ Macrocyclic Schiff's base (condensation product of thiosemicarbazide 
hydrochloride and malonanilic acid hydrazone) copper (II) complexes exhibited remarkable anticancer potency $(7.21 \pm 0.1 \mu \mathrm{g} / \mathrm{mL})$ toward MCF-5 may be due to reducing environment. ${ }^{58,59}$

All the compounds inhibited the cancer cells; MDA-MB-231, MCF-7 and A431 higher ( $\mathrm{IC}_{50}$ 0.32-2.05 $\mu \mathrm{M})$ than that of the control compound $\left(\mathrm{IC}_{50} 1.74-2.85 \mu \mathrm{M}\right)$.

\section{CONCLUSION}

The structures of the newly synthesized compounds comprised with isatin moiety $\left(\mathrm{L}_{1}\right.$ and $\left.\mathrm{L}_{2}\right)$ and their copper (II) complexes $\left(\mathrm{CuL}_{1}\right.$ and $\left.\mathrm{CuL}_{2}\right)$ were confirmed by elemental analysis and various spectroscopic methods. All the compounds showed higher anticancer potency than the control (DMSO) compound when these were tested against MDA-MB-231, MCF-7 and A431 cells. The compounds $\left(\mathrm{CuL}_{1}\right.$ and $\left.\mathrm{CuL}_{2}\right)$ contributed to decrease the percentage cell viability for MDA-MB-231, however, exhibited less effect on A431 and MCF-7. The coordination of thiosemicarbazones to metal ion enhanced their anticancer potency by 2-3 folds toward MDA-MB-231 but almost the same toward other cancerous cells. Compound $\mathrm{CuL}_{1}$ was found as a better anticancer agent (MDA-MB-231) compared to $\mathrm{CuL}_{2}$ as $\mathrm{CuL}_{1}$ showed less anti-proliferative activity on PNT2 (normal prostate epithelium immortalized with SV40) cell line. The modification of $\mathrm{N}(4)$ position by heterocyclic viz. thiomorpholinyl group exhibited better anticancer potency compared to alkyl groups. Anticancer potency results showed that the $\mathrm{CuL}_{1} \mathrm{molecule}$ may be used as the substitute for platinum-based anticancer drugs after its study at the molecular level.

\section{ACKNOWLEDGEMENT}

NAST (Nepal Academy of Science and Technology) and INSA (Indian National Science Academy) are acknowledged for providing financial support under the scheme of Ph. D. scholarship (2015/2016 AD) and INSA-NAST bilateral exchange program respectively and furnishing required instrumental facilities for characterization of compounds at the Department of Chemistry, Savitribai Phule Pune University, India to N. K. Singh. The authors would like to thank Dr. Agni Raj Koirala for providing EPR spectra (Sogang University, Seoul, Korea).

\section{REFERENCES}

1. B. B. Aggarwal, D. Danda, S. Gupta and P. Gehlot, Biochemical Pharmacology, 78(9), 1083(2009), https://doi.org/10.1016/j.bcp.2009.05.027

2. I. Warad, A. F. Eftaiha, M. A. Al-Nuri, A. I. Husein, M. Assal, A. Abu-Obaid, N. Al-Zaqri, T. B. Hadda and B. Hammouti, Journal of Materials and Environmental Science, 4(4), 542(2013).

3. L. Kelland, Nature Reviews Cancer, 7(8), 573(2007), https://doi.org/10.1038/nrc2167

4. C. Marzano, M. Pellei, F. Tisato and C. Santini, Anti-Cancer Agents in Medicinal Chemistry, 9(2), 185(2009), https://doi.org/10.2174/187152009787313837

5. M. Devereux, D. O'Shea, M. O'Connor, H. Grehan, G. Connor, M. McCann, G. Rosair, F. Lyng, A. Kellett, M. Walsh, D. Egan and B. Thati, Polyhedron, 26(15), 4073(2007), https://doi.org/10.1016/j.poly.2007.05.006

6. N. K. Singh, A. A. Kumbhar, Y. R. Pokharel and P. N. Yadav, Journal of Inorganic Biochemistry, 210(111134), (2020), https://doi.org/10.1016/j.jinorgbio.2020.111134

7. T. S. Lobana, R. Sharma, G. Bawa and S. Khanna, Coordination Chemistry Reviews, 253(7-8), 977(2009), https://doi.org/10.1016/j.ccr.2008.07.004

8. H. Beraldo and D. Gambino, Mini-Reviews in Medicinal Chemistry, 4(1), 31(2004), https://doi.org/10.2174/1389557043487484

9. K. Sampath, R. Ashokkumar, A. Venkatachalam and M. Shanmugaprakash, Rasayan Journal of Chemistry, 12(1), 257(2019), https://doi.org/10.31788/RJC.2019.1214099

10. A. I. Matesanz, A. B. Caballero, C. Lorenzo, A. Espargaro, R. Sabate, A. G. Quiroga and P. Gamez, Inorganic Chemistry, A-J(2020), https://doi.org/10.1021/acs.inorgchem.0c00467

11. N. K. Singh, S. Shrestha, N. Shahi, R. K. Choudhary, A. A. Kumbhar, Y. R. Pokhrel and P. N. Yadav, Asian Journal of Chemistry, 33(3), 557(2021), https://doi.org/10.14233/ajchem.2021.23004

12. B. Shakya, N. Shahi, F. Ahmad, P. N. Yadav and Y. R. Pokhrel, Bioorganic \& Medicinal Chemistry Letters, 29, 1677(2019), https://doi.org/10.1016/j.bmcl.2019.04.031 
RASĀYAN J. Chem.

Vol. 14 | No. 3 |1600-1610| July - September | 2021

13. B. Shakya and P. N. Yadav, Mini-Reviews in Medicinal Chemistry, 20(8), 638(2020), https://doi.org/10.2174/1389557519666191029130310

14. D. J. Bauer, L. S. Vincent, C. H. Kempe, P. A. Young and A. W. Downie, American Journal of Epidemiology, 90(2), 130(1969), https://doi.org/10.1093/oxfordjournals.aje.a121057

15. C. Santini, M. Pellei, V. Gandin, M. Porchia, F. Tisato and C. Marzano, Chemical Reviews, 114(1), 815(2014), https://doi.org/10.1021/cr400135x

16. J. P. Scovill, Phosphorus, Sulfur, and Silicon and the Related Elements, 60(1-2), 15(1991), https://doi.org/10.1080/10426509108233920

17. M. Muralisankar, S. Sujith, N. S. P. Bhuvanesh and A. Sreekanth, Polyhedron, 118, 103(2016), https://doi.org/10.1016/i.poly.2016.06.017

18. D. Tiwari, K. Basnet, J. Lamichhane, P. Niraula, S. Bhandari and P. N. Yadav, Asian Journal of Chemistry, 28(12), 2793(2016), https://doi.org/10.14233/ajchem.2016.20127

19. K. N. Aneesrahman, K. Ramaiah, G. Rohini, G. P. Stefy, N. S. P. Bhuvanesh and A. Sreekanth, Inorganica Chimica Acta, 492, 131(2019), https://doi.org/10.1016/j.ica.2019.04.019

20. M. Joseph, M. Kuriakose, M. R. P. Kurup, E. Suresh, A. Kishore and S. G. Bhat, Polyhedron, 25, 61(2006), https://doi.org/10.1016/j.poly.2005.07.006

21. M. C. Rodriguez- Arguelles, A. Sanchez, M. B. Ferrari, G. G. Fava, C. Pelizzi, G. Pelosi, R. Albertini, P. Lunghi and S. Pinelli, Journal of Inorganic Biochemistry, 73, 7(1999), https://doi.org/10.1016/S0162-0134(98)10085-5

22. A. Q. Ali, S. G. Teoh, N. E. Eltayeb, M. B. K. Ahamed and A. M. S. Abdul Majid, Polyhedron,74, 6(2014), DOI: 10.1016/j.poly.2014.02.025

23. M. Joseph, V. Suni, M. R. P. Kurup, M. Nethaji, A. Kishore and S. G. Bhat, Polyhedron, 23(18), 3069(2004), https://doi.org/10.1016/j.poly.2004.09.026

24. G. A. Bain, D. X. West, J. Krejci, J. Valdes-Martinez, S. Hernandez-Ortega and R. A. Toscano, Polyhedron, 16(5), 855(1997), https://doi.org/10.1016/S0277-5387(96)00323-3

25. J. Haribabu, G. R. Subhashree, S. Saranya, K. Gomathi, R. Karvembu and D. Gayathri, Journal of Molecular Structure, 1110, 185(2016), https://doi.org/10.1016/j.molstruc.2016.01.044

26. E. M. Jouad, G. Larcher, M. Allain, A. Riou, G. M. Bouet, M. A. Khan and X. D. Thanh, Journal of Inorganic Biochemistry, 86(2-3), 565(2001), https://doi.org/10.1016/s0162-0134(01)00220-3

27. F. A. Beckford, Jr. M. Shaloski, G. Leblanc, J. Thessing, L. C. Lewis-Alleyne, A. A. Holder, L. Li and N. P. Seeram, Dalton Transactions, 48, 10757(2009), https://doi.org/10.1039/b915081a

28. A. Q. Ali , S. G. Teoh, A. Salhin, N. E. Eltayeb, M. B. K. Ahamed and A. M. S. Abdul Majid, Spectrochimica Acta Part A: Molecular and Biomolecular Spectroscopy, 125, 440(2014), https://doi.org/10.1016/j.saa.2014.01.086

29. E. Labisbal, A. Sousa, A. Castineiras, J. A. Garcia-Vazquez, J. Romero and D. X. West, Polyhedron, 19, 1255(2000), https://doi.org/10.1016/S0277-5387(00)00383-1

30. F. Kandemirli, T. Arslan, B. Koksoy and M. Yilmaz, Journal of the Chemical Society of Pakistan, 31(3), 498(2009).

31. S. A. Ingle, A. N. Kate, A. A. Kumbhar, A. A. Khan, S. S. Rao and S. P. Gejji, Royal Society of Chemistry Advances, 5(59), 47476(2015), https://doi.org/10.1039/c5ra00020c

32. F. Bacher, O. Domotor, A. Chugunova, N.V. Nagy, L. Filipovic, S. Radulovic, E. A. Enyedy and V. B. Arion, Dalton Transactions, 44(19), 9071(2015), https://doi.org/10.1039/c5dt01076d

33. F. El-Saied, B. El-Aarag, T. Salem, G. Said, S. A. M. Khalifa and H. R. El-Seedi, Molecules, 24(3313), 25 pages (2019), https://doi.org/10.3390/molecules24183313

34. D. X. West, J. S. Ives, G. A. Bain, A. E. Liberta, J. Valdes-Martinez, K. H. Ebert and S. HernandezOrtega, Polyhedron,16(11), 1895(1997), https://doi.org/10.1016/S0277-5387(96)00468-8

35. F. A. Beckford and K. R. Webb, Spectrochimica Acta Part A: Molecular and Biomolecular Spectroscopy, 183, 158(2017), https://doi.org/10.1016/j.saa.2017.04.057

36. D. Kovala-Demertzi, M. A. Demertzis, P. N. Yadav, A. Castineiras and D. X. West, Transition Metal Chemistry, 24, 642(1999). 
RASĀYAN J. Chem.

Vol. 14 | No. 3 |1600-1610| July - September | 2021

37. P. N. Yadav, M. A. Demertzis, D. Kovala-Demertzi, A. Castineiras and D. X. West, Inorganica Chimica Acta, 332, 204(2002), https://doi.org/10.1016/S0020-1693(02)00710-7

38. R. Antony, S. T. David, K. Saravanan, K. Karuppasamy and S. Balakumar, Spectrochimica Acta Part A: Molecular and Biomolecular Spectroscopy, 103, 423(2013), https://doi.org/10.1016/j.saa.2012.09.101

39. R. Antony, S. T. D. Manickam, K. Saravanan, K. Karuppasamy and S. Balakumar, Journal of Molecular Structure, 1050, 53(2013), https://doi.org/10.1016/j.molstruc.2013.07.006

40. K. M. Vyas, R. G. Joshi, R. N. Jadeja, C. R. Prabha and V. K. Gupta, Spectrochimica Acta Part A: Molecular and Biomolecular Spectroscopy, https://doi.org/10.1016/j.saa.2011.09.039

41. S. Sharma, F. Athar, M. R. Maurya, F. Naqvi and A. Azam, European Journal of Medicinal Chemistry, 40(6), 557(2005), https://doi.org/10.1016/j.ejmech.2005.01.003

42. E. Pahontu, V. Fala, A. Gulea, D. Poirier and V. Tapcov and T. Rosu, Molecules, 18(8), 8812(2013), https://doi.org/10.3390/molecules18088812

43. S. A. Aly and A. S. Eldourghamy, International Journal of Research in Chemistry and Environment, 7(1), 38(2017).

44. M. S. Refat, I. M. El-Deen, Z. M. Anwer and S. El-Ghol, Journal of Molecular Structure, 920(1-3), 149(2009), https://doi.org/10.1016/j.molstruc.2008.10.059

45. A. L. Bail, H. Duroy and J. L. Fourquet, Materials Research Bulletin, 23(3), 447(1988), https://doi.org/10.1016/0025-5408(88)90019-0

46. J. R Carvajal, Fullprof Suite Program (Version 1.00), LaboratoireLeon, Brillouin (CEA/CNRS): CEA-Saclay, 91191, Gifsur-Yvette, Cedex, France (2007).

47. R. Kumar and P. Mathur, Spectrochimica Acta Part A: Molecular and Biomolecular Spectroscopy, 136, 818(2015), https://doi.org/10.1016/j.saa.2014.09.099

48. V. K. Peterson, Powder Diffraction, 20(1), 14(2005), https://doi.org/10.1154/1.1810156

49. M. Hricovini, M. Mazur, A. Sirbu, O. Palamarciuc, V. B. Arion and V. Brezova, Molecules, 23(4), 721(2018), https://doi.org/10.3390/molecules23040721

50. M. P. Sathisha, V. K. Revankar and K. S. R. Pai, Metal-Based Drugs, 2008, Article ID: 362105(2008), 11 pages (2008), https://doi.org/10.1155/2008/362105

51. R. Neiman and D. Kivelson, The Journal of Chemical Physics, 35(1), 156(1961), https://doi.org/10.1063/1.1731881

52. E. Turkkan, U. Sayin, N. Erbilen, S. Pehlivanoglu, G. Erdogan, H.U. Tasdemir, A. O. Saf, L. Guler and E. G. Akgemci, Journal of Organometellic Chemistry, 831, 23(2017), https://doi.org/10.1016/j.jorganchem.2016.12.020

53. G. Speie, J. Csihony, A. M. Whalen and C. G. Pierpont, Inorganic Chemistry, 35, 3519(1996), https://doi.org/10.1021/ic9508051

54. P. M. Krishna, B. S. Shankara and N. S. Reddy, International Journal of Inorganic Chemistry, 2013, Article ID: 741269 (2013), 11 pages(2013), https://doi.org/10.1155/2013/741269

55. K. D. Karlin, J. Zubieta (Eds.), Copper Coordination Chemistry: Biochemistry and Inorganic Perspectives, Adenine Press, Guilderland, NY (1983).

56. S. Chandra and Vandana, Spectrochimica Acta Part A: Molecular and Biomolecular Spectroscopy, 129, 333(2014), https://doi.org/10.1016/j.saa.2014.02.141

57. N. Graf and S. J. Lippard, Advanced Drug Delivery Reviews, 64(11), 993(2012), https://doi.org/10.1016/j.addr.2012.01.007

58. R. Kothari and A. Agrawal, Rasayan Journal of Chemistry, 13(3), 1672(2020), https://doi.org/10.31788/RJC.2020.1335717

59. B. Shakya, P. N. Yadav, J. Ueda and S. Awale, Bioorganic and Medicinal Chemistry Letters, 24, 458 (2014), https://doi.org/10.1016/j.bmcl.2013.12.044

[RJC-6341/2020]

1610

N(4)SUBSTITUTED 5-NITROISATIN THIOSEMICARBAZONES

N. K. Singh et al. 